ISSN: 1410-8917

Jurnal Kimia Sains \& Aplikasi

e-ISSN: 2597-9914

\section{Jurnal Kimia Sains dan Aplikasi Journal of Scientific and Applied Chemistry}

Journal homepage: http://ejournal.undip.ac.id/index.php/ksa

\title{
Metabolite Profiling of Java Turmeric (Curcuma xanthoriza) Essential Oil with Different Harvest Times
}

\author{
Mohamad Rafi ${ }^{a, b, *}$, Dewi Anggraini Septaningsih ${ }^{a}$, Rudi Heryanto ${ }^{a, b}$ \\ a Tropical Biopharmaca Research Center-Institute of Research and Community Services, Bogor Agricultural University, Jalan Taman \\ Kencana No. 3 Kampus IPB Taman Kencana, Bogor 16128, Indonesia \\ ${ }^{\mathrm{b}}$ Department of Chemistry, Faculty of Mathematics and Natural Sciences, Bogor Agricultural University, Jalan Tanjung Kampus IPB \\ Dramaga, Bogor 16680, Indonesia \\ *Corresponding author:mra@apps.ipb.ac.id
}

https://doi.org/10.14710/jksa.21.4.237-241

\section{Article Info}

Article history:

Received: 9 August 2018 Revised: 2 November 2018 Accepted: 5 November 2018 Online: 6 November 2018

Keywords:

metabolite profiling; java turmeric; Curcuma xanthoriza; gas chromatography-mass spectrometer; harvest times

Kata Kunci: pemrofilan metabolit; temulawak; Curcuma xanthoriza; kromatografi gas-spektrometer massa; waktu panen

\section{Abstract}

Java turmeric (Curcuma xanthoriza) is one of the native plants from Indonesia. Java turmeric is known as a medicinal plant with a high content of volatile oils. In this study, we investigated the chemical profile of java turmeric essential oil obtained by hydrodistillation associated with different harvesting times of the rhizome $(7,9$, and 11 months). The constituent of the essential oil was determined by using gas chromatography-mass spectrometer. About 19, 20 and 34 compounds were identified in 7, 9, and 11-month old java turmeric. Fifteen compounds were found in all samples namely $\beta$-elemene, zingiberene, $\gamma$-elemene, $\beta$-farnesene, $\alpha$-curcumene, benzofuran, $\alpha$-cedrene, epicurzerenone, ar-curcumene, germacrone, aromadendrene, $\alpha-$ longipene, trans-caryophilene, curcuphenol, and xanthorrhizol. This study showed the level of all compound detected in 7, 9, and 11 months old of java turmeric is different.

\section{Abstrak}

Temulawak (Curcuma xanthoriza) merupakan salah satu tumbuhan asli Indonesia. Temulawak diketahui sebagai tanaman obat dengan kandungan minyak atsiri yang tinggi. Dalam penelitian ini, kami melakukan investigasi profil kimia dari minyak atsiri temulawak yang diperoleh dengan distilasi yang terkait dengan masa panen rimpang yang berbeda ( 7,9 , dan 11 bulan). Kandungan dari minyak atsiri ditentukan dengan menggunakan kromatografi gas-spektrometer massa. Sekitar 19, 20, dan 34 senyawa teridentifikasi pada waktu panen ke 7, 9, dan 11 bulan. Dua belas senyawa ditemukan diseluruh sampel yaitu $\beta$-elemena, zingiberena, $\gamma$-elemena, $\beta$-farnesena, $\alpha$-kurkumena, benzofuran, $\alpha$-cedrena, epikurzerenon, ar-kurkumene, germakron, aromadendrena, $\alpha$-longipena, trans-karyofilena, curcuphenol, and xanthorrhizol. Hasil penelitian menunjukan komposisi dan jumlah senyawa yang terdeteksi pada temulawak dengan usia 7, 9, dan 11 bulan berbeda. 


\section{Introduction}

Indonesia dikenal memiliki sumberdaya alam yang kaya, diantaranya tanaman yang memiliki manfaat sebagai obat tradisional. Penggunaan tanaman obat dalam pengobatan tradisional telah banyak diuji dan diteliti kandungan yang terdapat dalam tanaman tersebut yang berperan dalam menimbulkan aktivitas biologis tertentu. Salah satu yang telah banyak dimanfaatkan sebagai tanaman obat di Indonesia yaitu temulawak yang termasuk dalam family Zingiberaceae. Kandungan senyawa atsiri dalam rimpang segar temulawak diketahui sekitar $0.19 \%$ dengan kandungan utama yaitu1,8-sineol, kurzerenon, xantorizol, $\beta$-kurkumena, zingiberena, $\beta$ bisabolol, dan ar-kurkumena $[1,2]$. Senyawa $\alpha-$ kurkumena pada temulawak diketahuidapat menghambat aktivitas enzimlipase sementara xantorizol bertanggung jawab untuk penghambatan pertumbuhan bakteri P. acnes [3]. Beberapa penelitian lainnya senyawa xantorizol pada minyak atsiri temulawak menunjukan potensinya sebagai antioksidan, antiinflamasi, antihipertensi, antihiperglikemik, dan antimikrobial [4, 5]. Penelitian lainnya menunjukkan minyak atsiri temulawak dapat menurunkan LDL-kolesterol dan bobot badan pada tikus [6].

Aktivitas biologis yang dimiliki oleh suatu tanaman tidak hanya berasal dari satu komponen saja akan tetapi dapat ditimbulkan dari beberapa senyawa yang dikandungnya dan dimungkinkan saling bersinergi dalam menimbulkan aktivitas biologis tertentu tersebut. Komposisi dan jumlah senyawa aktif terutama metabolit sekunder dalam suatu tanaman akan menentukan kualitas maupun khasiat yang ditimbulkan dari tanaman tersebut. Komposisi dan konsentrasi metabolit sekunder pada minyak atsiri temulawak tidak dapat dijamin selalu konstan mengingat adanya berbagai faktor yang mempengaruhinya seperti kondisi lingkungan tempat tumbuh, iklim, umur tanaman, cara panen, tahap siklus vegetatif, variasi musiman serta waktu pemanenan [710].

Suatu pendekatan yang berkembang saat ini yaitu metabolomik dapat digunakan dalam menentukan atau mengidentifikasi senyawa yang terdapat pada suatu sampel seperti tanaman obat [11]. Dalam metabolomik, spektrometer massa yang dikombinasikan dengan kromatografi gas dianggap sebagai kunci dalam teknologi analitik untuk identifikasi senyawa volatil. Teknik tandem ini umumnya digunakan karena ketertiruan dan kemampuannya yang baik untuk mengidentifikasi senyawa volatil pada suatu sampel biologis yang kompleks menggunakan pangkalan data senyawa yang komprehensif [12]. Dalam studi ini, kromatografi gasspektrometer massa (KG-SM) digunakan untuk pemrofilan metabolit yang ada dalam minyak atsiri rimpang temulawak dengan usia rimpang saat panen yaitu 7, 9, dan 11 bulan untuk pertama kalinya. Pemilihan usia rimpang didasarkan pada waktu panen rimpang temulawak yang umumnya dilakukan pada bulan ke 9, dan ditambah dengan sebelum dan sesudah waktu tersebut untuk melihat adanya perubahan komposisi metabolit volatil jika masa panen yang berbeda. Penelitian ini akan memberikan gambaran komposisi dan konsentrasi senyawa dalam minyak atsiri temulawak dengan umur rimpang yang berbeda. Adanya informasi ini dapat dijadikan sebagai suatu kriteria dalam menentukan waktu panen temulawak yang bergantung pada target senyawa kimia yang diinginkan nantinya.

\section{Metode}

\subsection{Preparasi sampel}

Rimpang temulawak dipanen pada bulan 7 (Mei 2016), 9 (Juli 2016) dan 11 (September 2016) setelah masa tanam di kebun Pusat Studi Biofarmaka Tropika, Institut Pertanian Bogor, Indonesia. Sampel segar temulawak selanjutnya dicuci dan dipotong. Sebanyak $2.5 \mathrm{~kg}$ rimpang segar ditimbang dan diekstraksi metabolit volatilnya dengan cara distilasi menggunakan perangkat distilasi (Gambar 1). Distilasi dilakukan selama 4 jam pada suhu 95-105 ${ }^{\circ} \mathrm{C}$ untuk menghasilkan minyak atsiri temulawak. Distilat yang diperoleh didiamkan beberapa saat dan minyak atsiri dipisahkan dari campurannya dengan air menggunakan corong pisah.

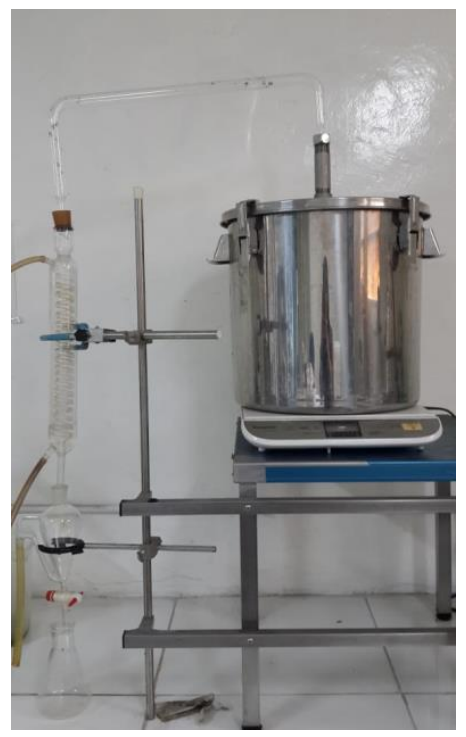

Gambar 1. Peralatan distalasi untuk proses penyulingan minyak atsiri rimpang temulawak

\subsection{Penentuan metabolit minyak atsiri rimpang temulawak dengan KG-SM}

Minyak atsiri temulawak yang diperoleh dari hasil distilasi selanjutnya dianalisis menggunakan KG-SM Agilent seri GC 7890 dan MS 6950. Kondisi alat yang digunakan yaitu gas pembawa helium diatur alirannya sebesar $1 \mathrm{~mL} /$ menit, suhu injektor sebesar $250^{\circ} \mathrm{C}$ dengan teknik injeksi split. Kolom kapiler KG dari J\&W, tipe HP$5 \mathrm{~ms}, 30 \mathrm{~m} \times 0.25 \mathrm{~mm}$, ketebalan film $0.25 \mu \mathrm{m}$ dengan suhu kolom $40-280^{\circ} \mathrm{C}$ diatur dengan laju kenaikan suhu sebesar $10^{\circ} \mathrm{C} /$ menit. Sebanyak $2 \mu \mathrm{L}$ minyak atsiri 
temulawak diinjeksikan ke dalam KG-SM. Total waktu elusi ditetapkan selama 30 menit. Kromatogram yang diperoleh dari kromatografi gas kemudian dianalisis dengan spektrometri massa untuk mendapatkan pola spektrum massa.

\subsection{Evaluasi Data}

Hasil analisis selanjutnya dievaluasi untuk mendapatkan informasi senyawa yang terkandung dalam minyak atsiri temulawak. Identifikasi komponen kimia ditentukan melalui evaluasi spektrum massa dengan menyocokkan pola spektra pada mass spectra library Wiley 8 dan National Institute of Standards and Technology (NIST). Proporsi relatif masing-masing komponen minyak ditunjukkan sebagai persentase relatif terhadap luas puncak total.

\section{Hasil dan Pembahasan}

Minyak atsiri rimpang temulawak segar dengan perbedaan waktu panen diperoleh kadarnya sebesar $0.0353 \%, 0.0467 \%$, dan $0.0611 \%$ masing-masing pada bulan ke 7, 9, dan 11. Masa panen yang lebih lama menunjukkan kadar minyak atsiri yang lebih besar. Perbedaan waktu panen ini juga memberikan perbedaan komposisi maupun jumlah metabolit kimia yang terkandung dalam minyak atsiri rimpang temulawak. Hal ini membuktikan bahwa umur tanaman merupakan salah satu faktor yang dapat menyebabkan perbedaan kadar metabolit yang terkandung dalam temulawak. Profil metabolit dalam minyak atsiri rimpang temulawak menggunakan KG-SM menunjukan kemiripan pola kromatogram (Gambar 2). Intensitas tiap puncak mengalami peningkatan seiring dengan umur rimpang temulawak yang semakin tua. Identifikasi metabolit volatil pada tiap sampel dilakukan menggunakan pangkalan data berdasarkan kecocokan pola fragmentasi spektrum massanya.

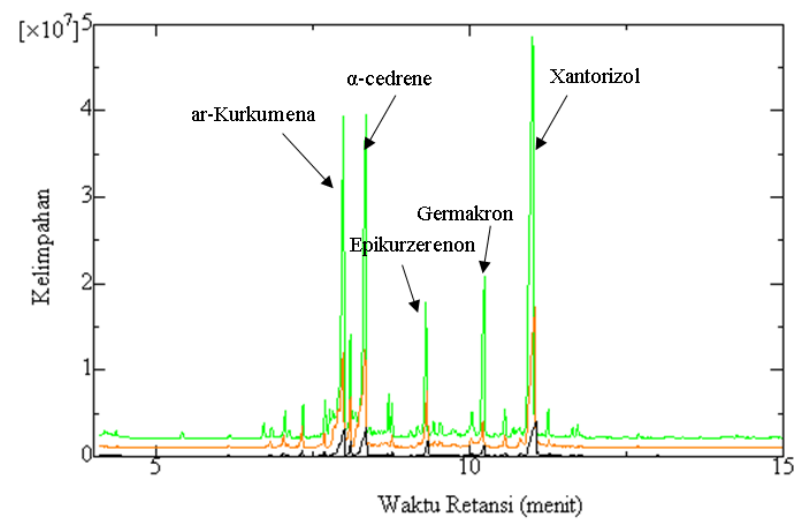

Gambar 2. Profil kromatogram KG-SM minyak atsiri temulawak pada waktu panen yang berbeda (hitam = bulan ke 7, jingga = bulan ke 9, hijau = bulan ke 11)

Sebanyak 29 senyawa kimia berhasil diidentifikasi dalam minyak atsiri rimpang temulawak yang dipanen pada bulan ke 11. Delapan belas senyawa teridentifikasi pada rimpang temulawak yang dipanen bulan ke 7 dan 20 senyawa pada bulan ke 9 (Tabel 1). Secara keseluruhan sebanyak 34 senyawa kimia berhasil diidentifikasi dari tiga sampel minyak atsiri temulawak yang digunakan. Senyawa penyusun minyak atsiri temulawak tersebut didominasi oleh senyawa kimia dari golongan terpenoid khususnya monoterpena dan seskuiterpena. Secara umum genus Curcuma memang mayoritas mengandung senyawaan terpenoid. Terpenoid berasal dari pembentukan isoprena dari asam asetat melalui jalur asam mevalonat. Penggabungan kepala dan ekor dua unit isoprena akan membentuk mono-, seskui-, di-, sesterdan poli-terpenoid, dan penggabungan ekor dan ekor dari unit C-15 atau C-20 akan menghasilkan triterpenoid dan steroid [13].

Tabel 1. Senyawa kimia dalam minyak atsiri rimpang temulawak dengan waktu panen 7, 9, dan 11 bulan

\begin{tabular}{|c|c|c|c|c|c|}
\hline \multirow[t]{2}{*}{ No } & \multirow{2}{*}{$\begin{array}{l}\text { Waktu } \\
\text { Retensi } \\
\text { (menit) }\end{array}$} & \multirow[t]{2}{*}{ Senyawa } & \multicolumn{3}{|c|}{$\%$ Area } \\
\hline & & & Bulan 7 & Bulan 9 & $\begin{array}{l}\text { Bulan } \\
\text { Ke-11 }\end{array}$ \\
\hline 1. & 4.394 & Terpineol & 0.24 & & \\
\hline 2. & 5.422 & Asam hidroksinamat, metil ester & & & 0.18 \\
\hline 3. & 6.186 & $\alpha$-terpinena & & 0.25 & 0.16 \\
\hline 4. & 6.722 & Asam sinamat, metil ester & & & 0.52 \\
\hline 5. & 6.827 & $\beta$-elemena & 0.78 & 0.77 & 0.44 \\
\hline 6. & 7.04 & Zingiberena & 1.28 & 1.33 & 0.90 \\
\hline 7. & 7.104 & trans-karyofilena & 0.35 & 0.34 & 0.31 \\
\hline 8. & 7.332 & $\checkmark$-elemena & 1.90 & 1.85 & 0.92 \\
\hline 9. & 7.69 & $\beta$-farnesena & 1.89 & 1.75 & 1.39 \\
\hline 10. & 7.778 & Kurkumena & 18.67 & 18.70 & 16.43 \\
\hline 11. & 8.103 & Benzofuran & 4.89 & 4.26 & 3.91 \\
\hline 12. & 8.204 & $\alpha$-cedrena & 20.10 & 19.83 & 16.15 \\
\hline 13. & 8.405 & Zingiberena & & 0.62 & \\
\hline 14. & 8.417 & $\alpha$-kopaena & 0.57 & & \\
\hline 15. & 8.695 & Germakrena B & 1.17 & 1.31 & 1.87 \\
\hline 16. & 8.768 & Zingiberena & 0.94 & 0.91 & 0.88 \\
\hline 17. & 9.062 & $\alpha$-cedrena & & & 0.23 \\
\hline 18. & 9.181 & trans-2-(Okt-1-enil)pyridin & & & 0.62 \\
\hline 19. & 9.326 & Epikurzerenon & 6.70 & 6.89 & 4.74 \\
\hline 20. & 9.443 & Aromadendrena & 0.38 & 0.94 & 0.84 \\
\hline 21. & 9.535 & $\alpha$-Longipena & 0.53 & 0.75 & 1.06 \\
\hline 22. & 9.736 & $\begin{array}{l}\text { 1H-indena, 1-etillidenaoktahidro-7a- } \\
\text { metil-, (1E,3a.alfa.,7a.beta.) }\end{array}$ & & 0.34 & \\
\hline 23. & 9.737 & $\beta$-Eudesmol & & & 0.75 \\
\hline 24. & 9.783 & $\beta$-Guaiena & & & 0.57 \\
\hline 25. & 10.028 & r-kurkumena & & 1.40 & \\
\hline 26. & 10.042 & Bergamotena & & & 2.34 \\
\hline 27. & 10.232 & Germakron & 4.19 & 3.74 & 7.40 \\
\hline 28. & 10.567 & Kurkufenol & 1.14 & 1.01 & 1.97 \\
\hline 29. & 11.010 & Xantorizol & 31.89 & 31.79 & 28.95 \\
\hline 30. & 11.644 & $\alpha$-Guaiena & & & 0.27 \\
\hline 31. & 12.701 & Metil palmitat & & & 0.11 \\
\hline 32. & 16.756 & $\begin{array}{l}\text { Asam heksanadioat, bis(2-etilheksil) } \\
\text { ester }\end{array}$ & & & 0.98 \\
\hline 33. & 22.923 & $\begin{array}{l}\text { 2-Benzyl-6-metil-4(3H)- } \\
\text { pirimidinon }\end{array}$ & & & 0.46 \\
\hline 34. & 25.236 & Metil oleanonat & & & 0.24 \\
\hline
\end{tabular}

Tiga puncak dengan intensitas terbesar dari ketiga waktu panen yang terdeteksi memiliki waktu retensi sebesar 7.778, 8.204, dan 11.010 menit (Gambar 1). Ketiga puncak tersebut secara berturut-turut diidentifikasi sebagai $\alpha$-kurkumena, $\alpha$-cedrena, dan xantorizol berdasarkan spektrum massanya (Gambar 3). Xantorizol merupakan komponen yang memiliki intensitas terbesar 
dan terdeteksi pada tiap waktu panen/umur rimpang. Berdasarkan profil kromatogram KG-SM yang diperoleh, xantorizol dengan konsentrasi terbesar terdapat dalam minyak atsiri temulawak yang dipanen pada bulan ke-11 dibandingkan dengan waktu panen lainnya. Akan tetapi untuk persentase area relatif xantorizol berbanding terbalik dengan luas puncaknya karena pada waktu panen bulan ke-11 senyawa yang teridentifikasi lebih banyak dibandingkan pada dua waktu panen lainnya. Dua komponen utama selanjutnya adalah $\alpha$-cedrena (8.204 menit) dan $\alpha$-kurkumena (7.778 menit). Telah diketahui secara umum xantorizol merupakan senyawa mayor dalam temulawak dan telah digunakan sebagai senyawa penciri untuk menentukan kualitas rimpang maupun minyak atsiri temulawak [2, 14]. Senyawa lain yang berhasil diidentifikasi pada tiga waktu panen yang digunakan yaitu $\alpha$-longipena, germakron, kurkufenol, epikurzerenon, aromadendrena, germakrena $B, \beta-$ elemena, trans-karyofilena, $\gamma$-elemena, $\beta$-farnesena, ar-kurkumena, benzofuran, dan zingiberena.
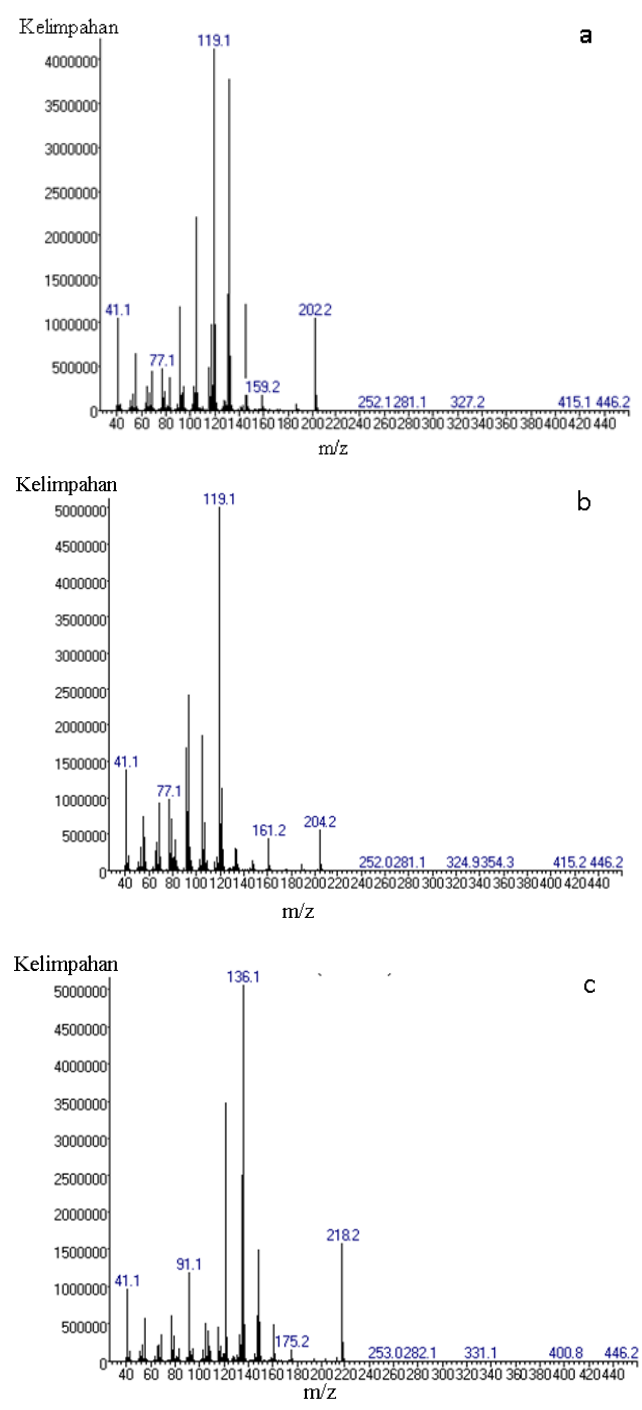

Gambar 3. Spektrum massa tiga puncak utama minyak atsiri temulawak kurkumena (a), $\alpha$-cedrena (b), dan xantorizol (c).
Zingiberena terbentuk melalui biosintesis farnesil difosfat dengan pergeseran 1,3-hidrida. Melalui proses yang sama dapat terbentuk $\gamma$-kurkumena dengan pergeseran 1,2-hidrida, tetapi $\gamma$-kurkumena hanya terdeteksi pada bulan ke 9. Senyawa $\beta$-elemena yang terdeteksi meningkat seiring dengan waktu panen berasal dari produk degradasi termal dari germakrena $\mathrm{A}$ [15]. Beberapa senyawa terdeteksi hanya di bulan ke 7 yaitu terpineol dan $\alpha$-kopaena. Senyawa $\alpha$-terpinena mulai terdeteksi pada bulan ke 9 dan mengingkat kandungan di bulan ke 11. Senyawa yang hanya terdeteksi pada bulan ke 11 yaitu trans-2-(okt-1-enil)piridin $(0.62 \%)$, asam sinamat, metil ester $(0.52 \%)$, asam hidroksinamat, metil ester ( $0.18 \%), \beta$-eudesmol (0.75\%), bergamotena $(2.34 \%)$, metil palmitat $(0.11 \%)$, asam heksanadioat, bis(2-etilheksil) ester (0.98\%), 2-Benzil6-metil-4(3H)-pirimidinon $(0.46 \%)$, metil oleanonat $(0.24 \%), \alpha$-guaiena $(0.27 \%)$, dan $\beta$-guaiena (0.57\%). Berdasarkan hasil yang diperoleh dapat memberikan informasi bahwa temulawak merupakan sumber senyawa seskuiterpenoid yang melimpah terutama untuk xantorizol sebagai senyawa mayornya. Selain itu dengan kemungkinan adanya proses degradasi beberapa senyawa menjadi bentuk lainnya memungkinkan pada umur rimpang temulawak 11 bulan terdeteksi senyawa yang lebih banyak dibandingkan dengan dua waktu panen lainnya. Akan tetapi masih perlu dilakukan studi lanjutan apakah waktu panen yang lebih lama akan lebih meningkatkan jumlah metabolit volatil pada temulawak.

\section{Simpulan}

Minyak atsiri rimpang temulawak dengan perbedaan waktu panen menunjukan kadar yang meningkat dengan masa waktu panen yang lebih lama. Minyak atsiri temulawak yang dipanen pada baik bulan ke 7, 9 dan 11 terdiri atas 18, 20, dan 29 penyusun dengan 3 komponen tertinggi yaitu xantorizol, kurkumena, dan $\alpha$-cedrena. Berdasarkan profil kromatogram KG-SM, kandungan ketiga senyawa ini meningkat jumlahnya seiring dengan lamanya waktu panen.

\section{Daftar Pustaka}

[1] S. Jarikasem, S. Thubthimthed, K. Chawananoraseth, T. Suntorntanasat, Essential Oils from Three Curcuma Species Collected in Thailand, ActaHortic., 677, (2005) 37-41 https://doi.org/10.17660/ActaHortic.2005.677.4

[2] Ibrahim Jantan, Fadlina Chany Saputri, Muhammad Naeem Qaisar, Fhataheya Buang, Correlation between Chemical Composition of Curcuma domestica and Curcuma xanthorrhiza and Their Antioxidant Effect on Human Low-Density Lipoprotein Oxidation, Evidence-Based Complementary and Alternative Medicine, 2012, (2012) 1-10 http://dx.doi.org/10.1155/2012/438356

[3] Irmanida Batubara, Iren Julita, Latifah K. Darusman, Ali Mahmoud Muddathir, Tohru Mitsunaga, Flower Bracts of Temulawak (Curcuma Xanthorrhiza) for 
Skin Care: Anti-acne and Whitening Agents, Procedia Chemistry, 14, (2015) 216-224 https://doi.org/10.1016/j.proche.2015.03.031

[4] Helen P. A. Mary, Gomathy K. Susheela, S. Jayasree, A. M. Nizzy, B. Rajagopal, S. Jeeva, Phytochemical characterization and antimicrobial activity of Curcuma xanthorrhiza Roxb, Asian Pacific Journal of Tropical Biomedicine, 2, 2, Supplement, (2012) S637S640 https://doi.org/10.1016/S2221-1691(12)602883

[5] Seok Fang Oon, Meenakshii Nallappan, Thiam Tsui Tee, Shamarina Shohaimi, Nur Kartinee Kassim, Mohd Shazrul Fazry Sa'ariwijaya, Yew Hoong Cheah, Xanthorrhizol: a review of its pharmacological activities and anticancer properties, Cancer cell international, 15, (2015) 100-100 http://dx.doi.org/10.1186/s12935-015-0255-4

[6] Endang Darmawan, Suwijiyo Pramono, Essential Oil of Javanese Turmeric (Curcuma xanthorrhiza, Roxb) Decrease Level of LDL-Cholesterol and Body Weight In Rats, Indonesian Journal of Cancer Chemoprevention, $7, \quad 1, \quad$ (2016) 6-8 http://dx.doi.org/10.14499/indonesianjcanchemopr ev7iss1pp6-8

[7] Hussein El-Zaeddi, Juan Martínez-Tomé, Ángel Calín-Sánchez, Francisco Burló, Ángel CarbonellBarrachina, Volatile Composition of Essential Oils from Different Aromatic Herbs Grown in Mediterranean Regions of Spain, Foods, 5, 2, (2016) 41 https://doi.org/10.3390/foods5020041

[8] H. R. Khazaie, F. Nadjafi, M. Bannayan, Effect of irrigation frequency and planting density on herbage biomass and oil production of thyme (Thymus vulgaris) and hyssop (Hyssopus officinalis), Industrial Crops and Products, 27, 3, (2008) 315-321 https://doi.org/10.1016/j.indcrop.2007.11.007

[9] Nancy W. Callan, Duane L. Johnson, Malvern P. Westcott, Leon E. Welty, Herb and oil composition of dill (Anethum graveolens L.): Effects of crop maturity and plant density, Industrial Crops and Products, 25, 3, (2007) 282-287 https://doi.org/10.1016/j.indcrop.2006.12.007

[10] SA Petropoulos, D Daferera, CA Akoumianakis, HC Passam, MG Polissiou, The effect of sowing date and growth stage on the essential oil composition of three types of parsley (Petroselinum crispum), Journal of the Science of Food and Agriculture, 84, 12, (2004) 1606-1610 http://dx.doi.org/10.1002/jsfa.1846

[11] B.J. Nikolau, Eve Syrkin Wurtele, Concepts in Plant Metabolomics, Springer Netherlands, 2007.

[12] Katja Dettmer, Pavel A. Aronov, Bruce D. Hammock, Mass spectrometry-based metabolomics, Mass Spectrometry Reviews, 26, 1, (2007) 51-78 http://dx.doi.org/10.1002/mas.20108

[13] Tri Dewanti Widyaningsih, Novita Wijayanti, Nur Ida Panca Nugrahini, Pangan Fungsional: Aspek Kesehatan, Evaluasi, dan Regulasi, Universitas Brawijaya Press, Malang, 2017.

[14] Hideji Itokawa, Koichi Takeya, Antitumor substances from higher plants, ChemInform, 24, 52, (1993)
[15] Hyun Jo Koo, David R. Gang, Suites of Terpene Synthases Explain Differential Terpenoid Production in Ginger and Turmeric Tissues, PLOS ONE, 7, 12, (2012) e51481 http://dx.doi.org/10.1371/journal.pone.0051481 